\title{
Politics of Artificial Intelligence Adoption: Unpacking the Regime Type Debate
}

\author{
H. Akın Ünver $\stackrel{*}{\text { A Arhan S. Ertan }}{ }^{\dagger}$
}

\begin{abstract}
What determines whether a country imports high-technology artificial intelligence (A.I.) products from the United States and China? Over the last decade, a growing body of literature began focusing on regime types and argue that authoritarian countries tend to import A.I. from China, whereas democratic countries from the United States. In this study we test this regime type hypothesis and find that both the US and China export to authoritarian and democratic countries alike, with China exporting to a larger number of countries. By employing multinomial logit with three leading A.I. trade datasets from Stanford University, Carnegie Endowment and World Bank, we find that Chinese A.I. exports are not driven by regime type, whereas American exports are. US A.I. exports are geared towards a smaller market of wealthy nations, whereas China supply to a broader market that is made up of a variety of regime types and GDP levels. Furthermore, we find that more countries import surveillance and policing-related A.I. products from the United States, compared to China, debunking a common mainstream view. We conclude by arguing military spending and GDP per capita are two of the strongest determinants of US A.I. exports, while a robust export pattern doesn't emerge with Chinese A.I.
\end{abstract}

Keywords: artificial intelligence, political regimes, development, democracy, authoritarianism

\section{Suggested Citation:}

Unver, A and Ertan, A (2021). "Politics of Artificial Intelligence Adoption: Unpacking the Regime Type Debate", in Filimowicz, M (editor), Democratic Frontiers: Algorithms and Society, Routledge

${ }^{*}$ Department of International Relations, Ozyegin University, Turkey, akin.unver@ozyegin.edu.tr, (ORCID: 0000-0002-6932-8325)

${ }^{\dagger}$ Department of International Trade, Bogazici University, Turkey, arhan.ertan@boun.edu.tr, (ORCID: 0000-0001-9730-8391) 


\section{Introduction}

Over the last decade, the diffusion and adoption of artificial intelligence (A.I.) and its related technologies across the world became a new flash- point of international competition. Although developed Western nations were initially better positioned to seize primacy in this new technological domain due to their stronger industrial base, the rapid advance and export strategies of Chinese high-tech industries have facilitated the diffusion of A.I. into countries with relatively less developed industrial and scientific foundations such as Ethiopia, Myanmar, and Zimbabwe. Such medium-cost, medium-capability A.I. exports so far included speech and face recognition, personal data push services, interactive interface technologies, data transmission infrastructure, and hardware devices required to transfer and process such data (Gravett, 2020). Often, these individual software and hardware bundles are exported under 'smart/ safe city' or 'smart policing' marketing strategies, although the fundamental 'detection-processing-prediction' task chain is near-identical and re-deployable across various projects (Roberts et al., 2021).

Chinese exports render automation at scale more affordable for developing countries by trading readily deployable A.I. tools cheaper, and in most cases, assist automation efforts of technologically less developed countries by reducing their dependence on trained human capital. This cost-effective Chinese A.I. export doctrine helps importer countries streamline decisions without having to train and employ armies of highly skilled programmers or engineers. While these countries cannot compete with more advanced and indigenously developed A.I. technologies of the US, EU, or Japan, they gain a clear advantage over their regional rivals that cannot afford Western A.I. technologies, yet also don't import from China due to their US alliance commitments (Aly, 2020). Over time, developing nations that embargo Chinese A.I. exports due to their alliance commitments to the US or the EU or due to ethical concerns about Chinese A.I. lose their competing power against other rivals that are bound by neither and look to Beijing for high-tech imports. Therein lies the Chinese comparative advantage in A.I. exports and the core of the global competition for technological influence between the US and China: Chinese strategy is as much about controlling global cost-effective A.I. demand and defining the mainstream market as it is about competing with the US.

As the technique and skillset ecosystem of A.I. expands, it becomes a general-purpose technology (GPT). The more the A.I. ecosystem grows and its constituent technologies become more complicated, what specifically such technologies entail becomes subject to greater debate. While the general consensus of A.I. definition still focuses on human-like behavior or decisions from machines, the scale and accuracy at which such expressions manifest form the basis of the international competition over algorithms, talent, and hardware that render these possible (Horowitz, 2018). In simpler terms, 'A.I. exports' are generally defined as hardware, algorithm and software units, bundles, and combinations that are intended to automate a large array of tasks that are repetitive in nature, but require human-like vision, decisions, and assessment procedures (Greitens, 2020; Helm et al., 2020). These mostly relate, but aren't exclusive to, a combination of advances in machine learning, robotic and vehicular autonomy, large-scale complex statistics, human-machine interaction, computer vision/language/agents, and neural networks. As a developing ecosystem of technologies, what 
specifically A.I. can do at the strategic level is still being hypothesized at the military, social, economic, healthcare, and educational domains with some applied convergence (Wang, 2019). At the very least, grasping the true impact of A.I. on broader global economic and social systems will take at least another decade, given how long it took for previous GPTs to be absorbed into their zeitgeist (Petralia, 2021). With such a lack of generally accepted parameters over what specifically 'A.I. technologies' entail and are expected to do, countries find it increasingly difficult to assess whether their national A.I. strategies are successful or how to strategize wielding A.I. in trade, defense, and diplomacy. This is why, while most countries realize that investing in A.I. is important, they are largely divided over how much they should invest in it (or which specific component) and which leading nations to cooperate with to maximize the chances of a successful A.I. adoption (Meltzer and Kerry, 2021).

Amidst this uncertainty, the US and China grew locked into a competition over global A.I. dominance, both trying to maximize their respective capacities and exporting their own products to the world. Both countries prioritize capitalizing on the rapid growth in computing capacity, producing and processing increasingly bigger datasets; develop newer and more sophisticated algorithms and statistical methods to increase the quality of their predictions, and creating an investment ecosystem that can financially sustain these advances over the long term. Additionally, both countries seek to leverage A.I. to build and maintain new alliance and partnership patterns that can bolster their international standing and export dominance. Quite often, this political feud spills over into complementary technologies such as $5 \mathrm{G}$ cellular networks, quantum computing, semiconductors, and autonomous vehicles, broadening the trenches of the competition over emerging technologies, and rendering this competition a truly global one with system-level balance of power repercussions Horowitz et al. (2018).

\section{Politics of Artificial Intelligence: The Regime Type Debate}

In the last few years, scholarship on how countries adopt and employ A.I. tools and techniques grew significantly. Amidst this debate, major fields of inquiry sought to explain the spread of such technologies from a diverse array of theories such as development and growth, organizational adaptation, welfare and inequality, politics, and international competition (Alsheibani et al., 2018; Weber and Schütte, 2019; Webster and Ivanov, 2020; Zerfass et al., 2020). Within the political science and international relations scholarship, researchers have largely focused on whether governance and political systems affect how countries adopt new technologies. In other words: does regime type (whether a country is democratic or authoritarian) affect whether or how countries adopt artificial intelligence (Levy, 2018; Malmborg and Trondal, 2021; Schiff et al., 2021; Unver, 2018)? As promising extensions of this research question, further inquiries emerged into whether automation at scale will be more conducive to democracy or authoritarianism or whether unemployment and labor shifts generated by mass automation will reinforce autocratic tendencies of governments (Feldstein, 2019b; Frank et al., 2019; Zeng, 2020). 
Since technology adoption is a multilayered process that is determined at the intersection of a nation's government, citizens, and corporations, the political system under which these actors operate determines the scope and depth of such adoption (Evans, 1995). In the case of A.I., technology companies that drive high-tech adoption rely on sound regulatory environment, uninterrupted and predictable funding streams, and an investment environment that is conducive for international collaborations and partnerships (Milner, 2006). In line with the adoption patterns of other digital technologies, when a political system is free enough to secure a rapid development of private technological enterprise and enable citizens and companies to use new products produced by such companies unhindered, one can expect democratic countries to lead in A.I (Corrales and Westhoff, 2006).

Governments have a number of incentives in providing a conductive environment for A.I. technology adoption. Automation at scale renders a wide array of tasks in national defense, industrial production, banking/finance, and communication faster at higher volumes and increasingly more accurate (Diamond, 2010; Viscusi et al., 2020). A robust A.I. infrastructure itself positions nations better to adopt rapidly developing advanced technologies and thereby increase the competitiveness of those countries' defense, commerce, industry, and trade sectors (Haner and Garcia, 2019). To that end, willingness to adopt and develop advanced A.I. know-how generates global interest irrespective of regime types.

Yet, there have been studies that emphasize particular characteristics of democracies to distinctly enable a faster and more robust adoption of newer technologies. According to this stream, freer political systems and less centralized economic systems are better positioned to create scientific and industrial ecosystems that can enable better adoption of digital technologies (Kimber, 1991; Leslie et al., 2021; Nemitz, 2018; Wright, 2020). Corrales and Westhoff (2006), for example, demonstrate that democracies, on average, adopted the Internet faster and with greater nationwide penetration compared to authoritarian governments. Milner (2006), however, posits that democracies are not inherently more conducive to the adoption of new technologies, but elite preferences in autocracies define whether that country will adopt an emerging technology. This line of argumentation suggests that if authoritarian leaders believe a new technology will reinforce their rule, they will create conducive funding and investment environment to facilitate new technology adoption. For example, an authoritarian country may restrict the adoption and spread of the Internet and social media due to their regime-weakening effects, but actively facilitate and encourage the development of an A.I. industry due to their defense and surveillance implications. In Acemoglu and Robinson (2000)'s words: 'agents who have political power and fear losing it who will have incentives to block technological progress'.

However, Stier (2015) introduces a temporal argument in his cross-sectional study, empirically demonstrating that after 2013, there are no clear differences in Internet adoption between democracies and authoritarian countries, as the latter have caught up rapidly once they learned how to manage and control digital communication outlets (Druzin and Gordon, 2018; Rød and Weidmann, 2015). In that vein, technology adoption can also be viewed as a matter of regime survival, whereby active elite preferences matter more than passive regime type effects. Once such technologies demonstrably reduce costs of surveillance and control, they trigger a very different form of technology diffusion across hybrid and authoritarian 
regimes that cannot be explained by the democratic technology diffusion literature (Choi and Jee, 2021). Kania (2021)'s exploration of Chinese People's Liberation Army doctrine on artificial intelligence is particularly important in this sense, as it is expected to influence defense doctrines of other developing nations that are likely to import A.I. components heavily from China. Kania (2021) demonstrates how China has situated its armed forces and revisionist territorial claims in the South China Sea as the main engine of its broader A.I. efforts, outlining that authoritarian countries with similar revisionist claims may find it more desirable to acquire advanced technologies from China rather than Western nations.

But why would A.I. adoption patterns flow across similar regime types? One line of scholarship explores whether A.I. is a distinctly liberal or illiberal technology. Wright (2020), for example, focuses on the surveillance-enhancing aspects of A.I. to posit that such technologies, under authoritarian hands, will reinforce further repression and will embolden other authoritarian countries to adopt A.I. tools that make it easier to engage in large-scale spying on citizens. To prevent such a scenario, he emphasizes the role of civil society and democratic institutions to bolster international A.I. governance norms to facilitate technology diffusion among democratic nations, thereby rendering authoritarian adoption of A.I. undesirable for developing nations. Lamensch (2021) posits a similar argument, demonstrating how A.I. in particular and digital technologies in general are more conducive for authoritarian tendencies rather than liberal ones by reducing the costs of large-scale surveillance. That said, she underlines the fact that a broad range of A.I. tools used by authoritarian regimes are developed and exported by democracies themselves, blurring the lines between various regime types and how much they contribute to global authoritarianism.

Polyakova and Meserole (2019), however, argue that it is no longer democracies alone that are exporting A.I. technologies to authoritarian countries, but Chinese and Russian low-cost options are increasingly clawing back market share from Western exports, creating distinct regime type cleavages in technological trade patterns. They argue in favor of stronger export controls to minimize the transfer of surveillance and A.I.-related technologies from democracies into authoritarian regimes and opt for targeted sanctions on critical technologies in more extreme cases. Similarly, by deploying a large dataset of A.I. adoption trends,Feldstein (2019b) outlines three main pathways for how A.I. can reinforce illiberalism: mass surveillance that disables popular movements and protests, localized surveillance to suppress dissent in protest-prone regions, and deploying organized large-scale disinformation to delegitimize the political opposition. He posits that while these techniques are problematic enough under Chinese control, exporting such technologies to bolster autocracies across the world reduces developing countries' reliance on Western A.I. exports, thereby bypassing the need to adopt democratic norms and practices as prerequisites to access advanced technologies.

As an increasing number of democratic regimes began importing A.I. tools from China, the regime type became particularly salient from an international alliances point of view especially on whether A.I. trading patterns will generate new alliance formations such as hybrid ones that include a mixture of regime types. Since post-World War II and post-Cold War world orders are built on institutionalizing cooperation among democracies and forming a unified bloc against authoritarian countries, A.I.-related conflict and cooperation patterns are generally expected to follow a similar course. Franke (2021), for example, situates the 
EU firmly within the US-led A.I. alliance system, arguing that regime type and democratic norms will remain as the fundamental conditions for cooperation and partnership patterns in the next decade. Additionally, she prescribes that to attain primacy in the new A.I. competition, the EU would have to prioritize bolstering the private sector and technology startups rather than state-led initiatives by individual member states. Horowitz (2018) argues that international alliance and balance of power shifts will largely be dictated by whichever country leads in the scientific and military advances in A.I. He warns that a USled A.I. supremacy is by no means guaranteed, and if the current trend in deep learning research continues, it might be likelier for China to create a new partnership regime - one that may even include most European countries - based on its lower-cost high technology exports.

As outlined in Johnson (2019), an increasing number of countries view A.I. as a strategic investment priority and view any progress in this field as a national security goal. As a testament to A.I.'s growing importance, while there were only three countries with national A.I. strategies in 2016, as of 2021, there are more than 60. In one of the most comprehensive of such analyses, Fatima et al. (2020) find great discrepancies over how countries discursively construct A.I. in their national strategy documents. They conclude that democratic countries with a lower technology base are more likely to emphasize ethical dimensions of A.I. in their national strategy documents compared to democratic or authoritarian/hybrid regimes with a stronger technology base. Yet, even countries with no national strategy documents are involved in strategic A.I. trade. Campbell (2008) focused on China's ex- ports to sub-Saharan African countries underlining that Beijing was reinforcing existing illiberal tendencies of countries by rendering repression easier. Zeng (2020) advances this argument further, positing that the fundamental Chinese A.I. strategy is to bolster states against societies and thereby attract surveillance-oriented developing countries into Chinese technology exports orbit.

From this survey, we arrive at the following hypotheses:

* H1: Authoritarian regimes are more likely to choose Chinese A.I. exports

* H2: Less developed and poorer countries are more likely to choose Chinese A.I. exports

* H3: Countries that have existing strong trade relations with China are more likely to acquire A.I. technologies from them

* H4: Authoritarian countries are more likely to acquire surveillance and repressionrelated A.I. technologies

* H5: Belt and Road Initiative (BRI) countries are more likely to acquire Chinese A.I. exports

\section{Data Sources and Methodology}

In order to test these hypotheses, we combined two of the most comprehensive datasets that dissect A.I. trade and adoption patterns across the world. The first of these datasets is the 
Artificial Intelligence Index1 published by Stanford University's Human-Centered Artificial Intelligence (HAI), which logs A.I. adoption trends across seven categories: research and development, technical performance, economy, A.I. education, ethical challenges of A.I., diversity in A.I., and A.I. policy and national strategy. These categories are then merged into the 'Global A.I. Vibrancy Tool', which measures countries' A.I.-related progress across 22 indicators, including conference papers, journal citations, patents, funded companies, and skill penetration. The second dataset we use is the A.I. Global Surveillance (AIGS) Index, published by Carnegie Endowment, which combines regime type scores, military expenditures, major tech firms in operation, and the type of A.I. technology used by 73 countries (Feldstein, 2019a). The dataset also contains information whether China, US, or Japan is actively involved in those countries' A.I. ecosystems. AIGS also uses Freedom House weighted average country scores, Economist Intelligence Unit (EIU) Democracy Index 2018 and V-Dem's Electoral Democracy Index, to measure regime type as well as Stockholm International Peace Research Institute's (SIPRI's) military expenditure dataset to measure budget and spending-related figures. BRI country information comes from Kliman and Grace (2018), and Chinese overseas direct investment figures are compiled from EIU. Our trade (export-import) data comes from World Bank's World Integrated Trade Solution (WITS) dataset. $^{1}$

In order to analyze our hypotheses, we estimate regression models in the following linear form:

$$
Y_{i}=\alpha+\beta_{x} X_{i}+\beta_{z} Z_{i}+\epsilon_{i}
$$

where $Y$ is one of our dependent variables, $X$ is a vector of explanatory and $Z$ is a vector of control variables in our dataset ${ }^{2}$ and $\epsilon$ is the random error term. As for the estimation method, we have utilized the multinomial logit since our dependent variable has more than two mutually exclusive and exhaustive categories which are nominal in nature and do not have a meaningful sequential order. Multinomial logit models are a direct generalization of the ordinary two-outcome (binary) logit models and are used to estimate relationships between an ordinal (categorical or ordered) dependent variable and a set of independent variables. In multinomial logit, an underlying score is estimated as a linear function of the independent variables and a set of cut-points and the error term is assumed to be logistically distributed. Parameter estimation is performed through an iterative maximum likelihood algorithm (Hausman and McFadden, 1984; Small and Hsiao, 1985).

\section{Findings}

Our results demonstrate a more nuanced picture with regard to the extent regime type influences whether countries prefer American or Chinese A.I. exports (Hypothesis-1). Primarily, we offer a more inequality- and development-oriented explanation (i.e., gross domestic product [GDP] differences between countries and whether a country is industrialized and has an existing strong technological base) rather than a regime type explanation (whether a country is democratic or authoritarian) over states' A.I.-related acquisition choices.

\footnotetext{
${ }^{1}$ Source: https://wits.worldbank.org/

${ }^{2}$ See Table 1 for the detailed list of these variables
} 
With regard to our Hypothesis-2, countries with a greater number of existing A.I. firms tend to rely on both American and Chinese A.I. investments, whereas countries with slightly fewer number of A.I. firms rely predominantly on the US. However, countries that have few or no A.I. firms import mainly from China (see Figure 1 and Table 1). This is an interesting finding, since the number of existing firms in a country and existing technological base push that technology ecosystem towards both the US and China rather than just the US alone. This means that top performer countries in A.I. diversify their technology imports between two technology superpowers and do not rely wholly on the US alone. However, countries with higher A.I. investment budgets prefer US A.I. exports, whereas countries with lower A.I. investment budgets import heavily from China, producing a clear inequality hypothesis (see Figure 2). Therefore, greater existing technological base, if measured by the number of existing A.I. firms, pushes countries to diversify into US and Chinese exports. However, if existing technological base is measured by countries' investment budgets, then such countries tend to rely primarily on the US.

As far as Hypothesis-3 is concerned, existing trade relations are strong determinants of countries' A.I. import choices. Countries where China covers a larger portion of imports than the US tend to import A.I. technologies from China at a significant rate (see Figure 4 and Table 1). Moreover, countries that have increasingly become more dependent on trade with China in the last 20 years (growth of imports from China versus from the US between 2000 and 2019), strongly prefer Chinese A.I. exports to American ones (see Figure 5 and Table 1). This kind of clear difference doesn't appear in countries where the EU is a dominant trade partner; in countries where the EU is the largest trading partner, preference for A.I. technology from China, US, or both show similar results (suggesting EU-origin A.I. export preferences). Yet, in countries where trade with the EU has grown stronger over the last 20 years, preference for Chinese A.I. imports is significantly lower (see Figure 6). This reinforces the hypothesis that Chinese A.I. exports fill the gap in countries where both American and European trade have dwindled, and thereby situate China as an alternative source of development funds in countries that cannot access any Western sources.

Exploring Hypothesis-5 yields additional insights that weaken the regime-type argument. Being a 'Belt and Road Initiative country' (BRI Group) is a strong indicator of whether a country imports such infrastructure from China (see Figure 3). However, even in non-BRI countries, preference is towards importing both from China and the US rather than heavily or solely from the US. This means that non-BRI countries choose both Chinese and American A.I. exports rather than US-made alone. Therefore, although BRI is a strong anchor that ties a wide range of countries to China's global efforts, Chinese A.I. presence is strong in countries that aren't within the BRI framework. This somewhat refutes arguments of a "new A.I. Cold War' between the US and China (Garcia, 2021), as in terms of global market dominance, China is the leading supplier of A.I. technologies to a broader and more numerous range of countries. In most countries the US export to, American A.I. firms have to compete with their Chinese counterparts.

As for our Hypothesis-1 and Hypothesis-4, with regard to 'authoritarian A.I. tools' such as facial recognition and surveillance exports, we see no clear difference between the US or Chinese-origin import preferences: facial recognition and related technologies are imported 
from either/both countries in a comparable fashion, weakening the US-led 'democratic A.I. exports' argument (see Figure 7 and Figure 8). In terms of perhaps the 'most authoritarian' of A.I. exports - smart policing systems - importers have a distinct preference for US-made exports or both US and Chinese offerings, further weakening the argument that China is the only country that exports authoritarian tools or that the US leads 'democratic A.I.' efforts. Further hammering in this point, a greater number of countries import surveillance-purpose A.I. tools from the US compared to China. In terms of exporting A.I. as a repressive tool, China and the US appear comparably involved.

Indeed, further delving into Hypothesis-1, we observe a weak relationship between freedom scores and whether countries prefer Chinese- or American-origin A.I. tools. Countries with higher freedom scores very slightly tend to import US-made A.I. tools, but China is a strong second, nullifying a great degree of regime type effects on A.I. imports. Countries that are listed as 'not free', 'partly free', and 'free', all tend to import A.I. from China more frequently, although the margin is larger with the former two (see Figure 14). Polyarchy scores also show a weak relationship between political systems and A.I. import preferences (see Figure 15). More interestingly, as regime scores improve, countries tend not to buy either from the US or China (suggesting they buy either from the EU or Japan) or from both the US and China. We further observe that electoral autocracies tend to buy more from China, but this is similarly valid for electoral democracies as well as liberal democracies (see Figure 9 and Figure 10 and Table 1). As far as regional variances go, Chinese A.I. exports dominate Africa and Asian continents, while they remain popular in Europe and Latin America as well. It is important to underline that there are no European countries in our dataset that are solely buying A.I. infrastructure from the US, but there are five European countries buying solely from China (see Figure 13).

The best explanation of A.I. import choices remain GDP per capita and income (see Figure 11 and Table 1). Countries with low, lower-middle and upper-middle income buy dominantly from China, while in high-income countries this gap narrows. Even then, richer countries tend to buy from both China and the US rather than being dependent on either. But most acutely, countries with a higher GDP per capita tend to buy more from the US than China, whereas countries that have a higher GDP tend to buy from both countries. Perhaps as a final nail in the coffin of the 'regime type' argument, countries that have a higher military expenditure budget tend to buy A.I. exports from the US in a larger volume. Countries with lower military budgets clearly prefer Chinese A.I. exports (see Figure 12).

\section{Discussion}

Overall, these results increase our skepticism towards the explanatory value of the 'regime type' argument and show a weak relationship between whether a country is democratic or authoritarian and whether it acquires A.I. technology predominantly from China or the US. Rather, current evidence demonstrates that not only authoritarian regimes, but also electoral and liberal democracies tend to import A.I. tools from China, often more exclusively than they import from the US. With the exception of a few wealthy liberal democracies, most countries - liberal democracies, electoral democracies, electoral autocracies, and closed 
autocracies - all choose Chinese exports, and in most cases, countries with a richer ecosystem of A.I. firms tend to import both from China and the US. With these findings, we argue that regime type is not a strong determinant of A.I. acquisition trends, especially in light of the fact that more countries buy smart policing and surveillance tools from the US than they do from China.

Two of the most powerful variables that explain whether countries adopt A.I. through China or the US are military spending and both the size and the per capita value of GDP. Wealthier countries with larger defense budgets tend to prefer US- origin A.I. equipment while China capitalizes on a larger A.I. market that includes all regime types except the wealthiest liberal democracies. In addition, there is currently no strong evidence to support the claim that countries import 'authoritarian A.I. tools' only from China and 'democratic tools' only from the US. Most acutely, countries buy both authoritarian and otherwise A.I. technologies from both China and the US, and in the case of surveillance-oriented technologies, the US has a distinct market edge. Furthermore, current data shows that global competition for A.I. dominance is largely driven by global inequalities - between a smaller group of wealthier countries that can afford to prioritize A.I. ethics and norms and a larger group of developing countries that are seeking more affordable and faster options to integrate emerging technologies into their national strategies.

These findings mean that the scholarship should move beyond the regime type dyad in assessing why countries buy Chinese or American A.I. exports and instead focus on comparative developmental explanations such as growth, regional trade competition, and affordability of technological adoption. Overall, our findings indicate that China will continue to exclusively trade with a larger number of countries, if it is the only country that is able to provide affordable A.I. exports at scale. It is important to underline that this doesn't mean that China is 'better' or 'stronger' in A.I. compared to the US, ${ }^{3}$ but merely that its A.I. export model will likely help it stay ahead of the US in terms of the number of countries it trades with exclusively (with no US competition). While important from a policy perspective; Western 'A.I. ethics' discourse will likely remain insignificant in the face of immediate growth and technological advancement needs of developing countries. Given the popularity of Chinese A.I. exports, the majority of countries out- side the US/EU alliance ecosystem will find it easy to turn away from Western A.I. exports that are more expensive than developing countries can reliably use, and come with ideological strings attached. Such turn towards Chinese A.I. exports are even visible in the EU (related analyses / figures are available upon request), where no country exclusively trades with the US on A.I. issues and opt for both Chinese and American offerings.

To conclude, although US-origin A.I. exports may be technologically more advanced, Chinese export strategy of offering more moderately priced, moderate-capability A.I. tools has resulted in significant popularity of the latter globally. Unless either the US or EU can produce a more imaginative economic technology-transfer model that can render high-tech development more affordable for developing countries, Western A.I. exports will likely remain within the 'rich countries club' and will not be adopted by the rest of the world. If that continues to be the case, China may well lead in A.I. in terms of the number of its

\footnotetext{
${ }^{3}$ For a comprehensive study on this matter, see Castro et al. (2019)
} 
trade partners, which can ultimately lead to Chinese diplomatic and political gains in other technology-related issues. In terms of how to alter this momentum, our suggestion is an outlier against other mainstream suggestions that urge building better norms, more comprehensive ethical guidelines, establish stronger Western institutions to safeguard A.I. ethics, or issue targeted sanctions against Chinese A.I. exports or countries that import such tools. While these are important, none of those suggestions are likely to shift developing countries away from Chinese A.I. exports - rather, they will more likely exclude and antagonize these countries, expediting China's ability to form a unified international bloc of developing countries on A.I. technology partnership.

Instead, we believe that the US and the EU have to build a new export model that can compete with China at the medium-cost, medium- capability A.I. exports range. Since Western exports are already unaffordable for the majority of the countries advancing in A.I., the only way to link those countries to the Western technology ecosystem is to offer more reliable and better-performing, mid-range exports at scale. We do not suggest either the US or Europe turn away from A.I. ethics or norms, but in order to be able to insist on those priorities, Western exports need to be decisively more preferable over Chinese exports at price-performance ratio. Ultimately, by breaking Western A.I. exports from its small 'rich countries club' bubble and by offering more efficient A.I. technologies can the West produce sufficient leverage to build international partnerships based on truly representative and inclusive global institutions and norms. 


\section{Figures and Table}

Figure 1: Chinese versus US A.I. import preference in sample countries according to the median number of existing A.I. firms

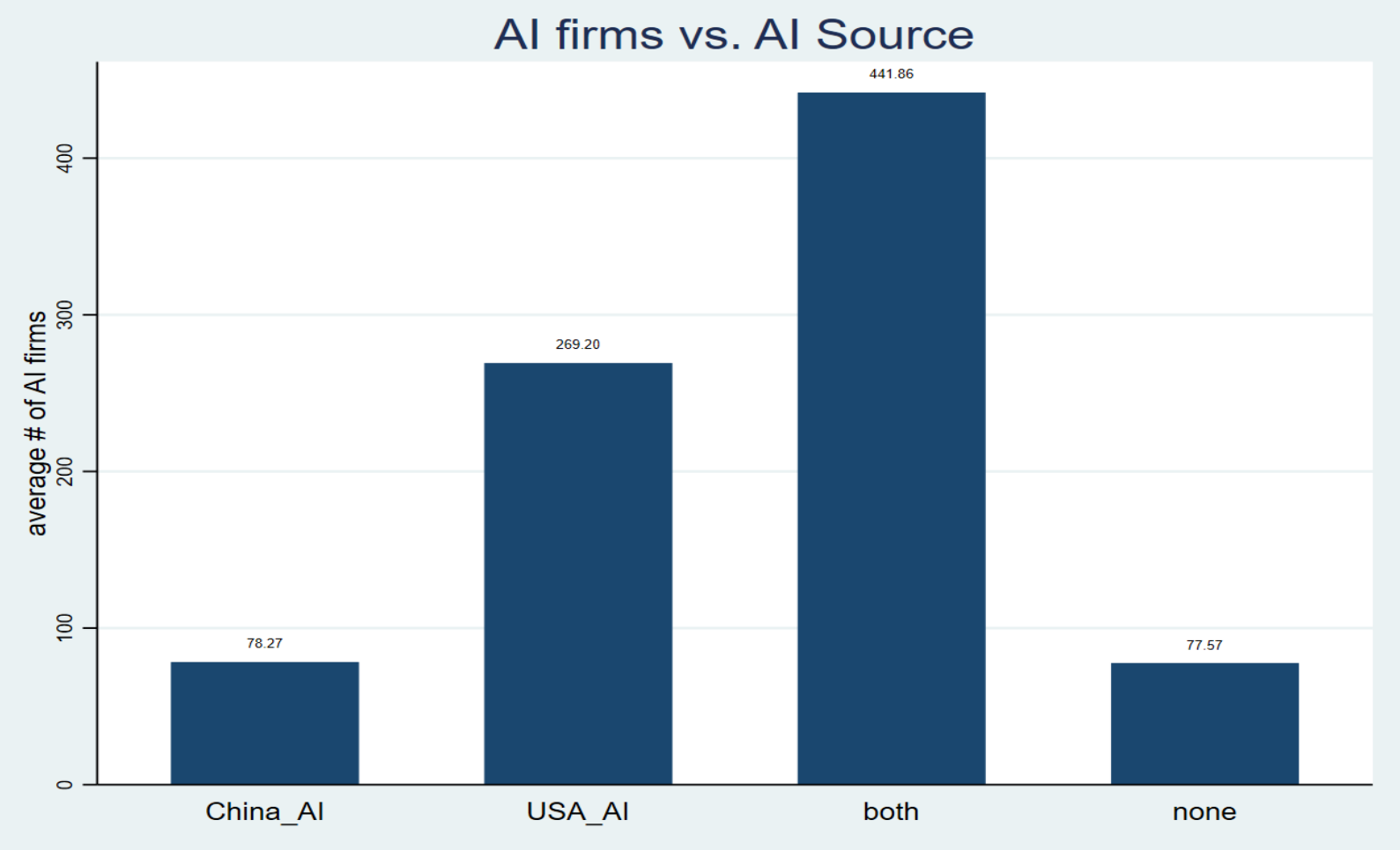


Figure 2: Chinese versus US A.I. import preference in sample countries according to the median size of existing A.I. investment

\section{Al investment vs. Al Source}

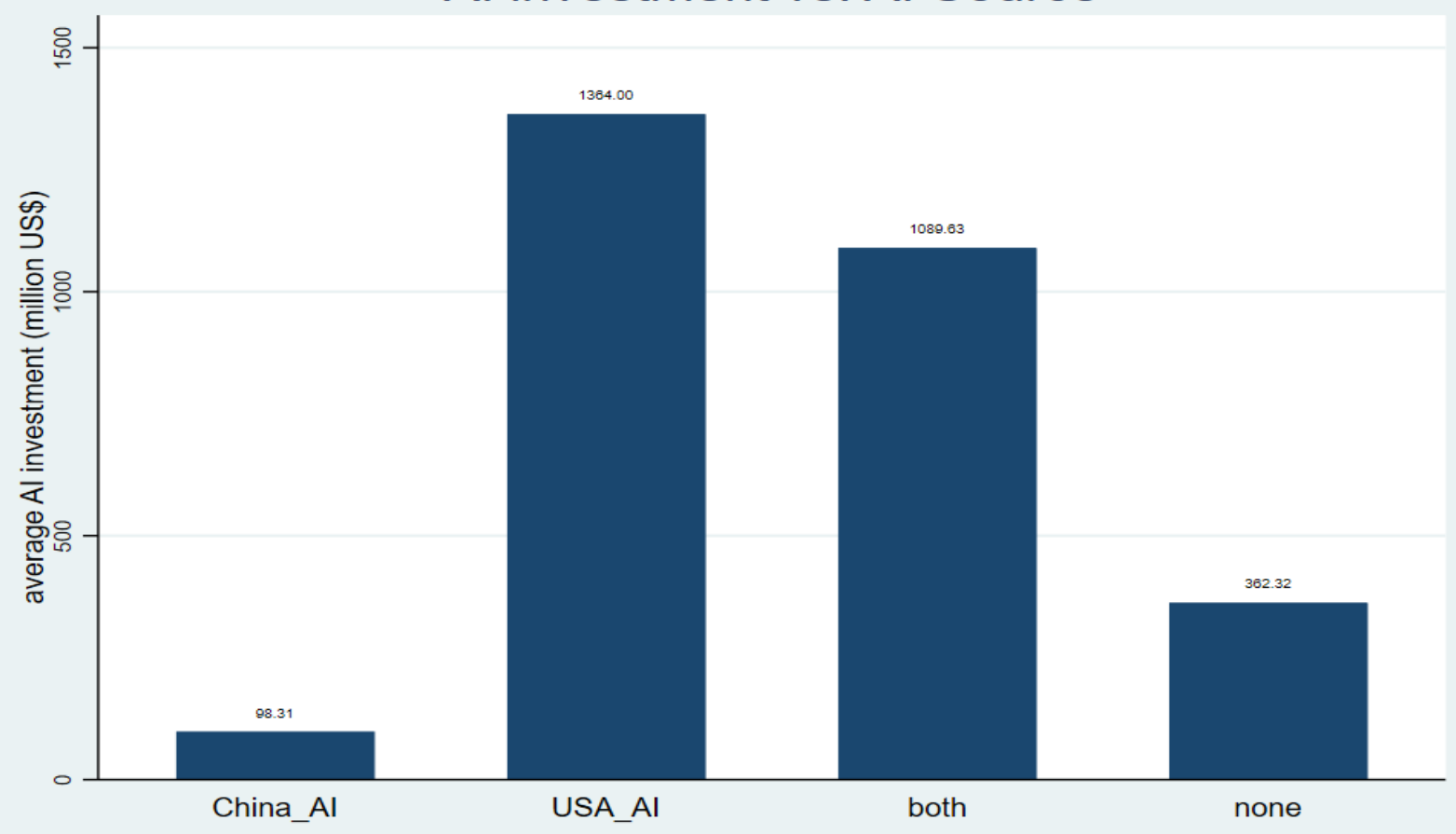


Figure 3: Chinese versus US A.I. import preference in sample countries by Belt \& Road Initiative participation

\section{Belt \& Road Initiative vs. Al Adoption}

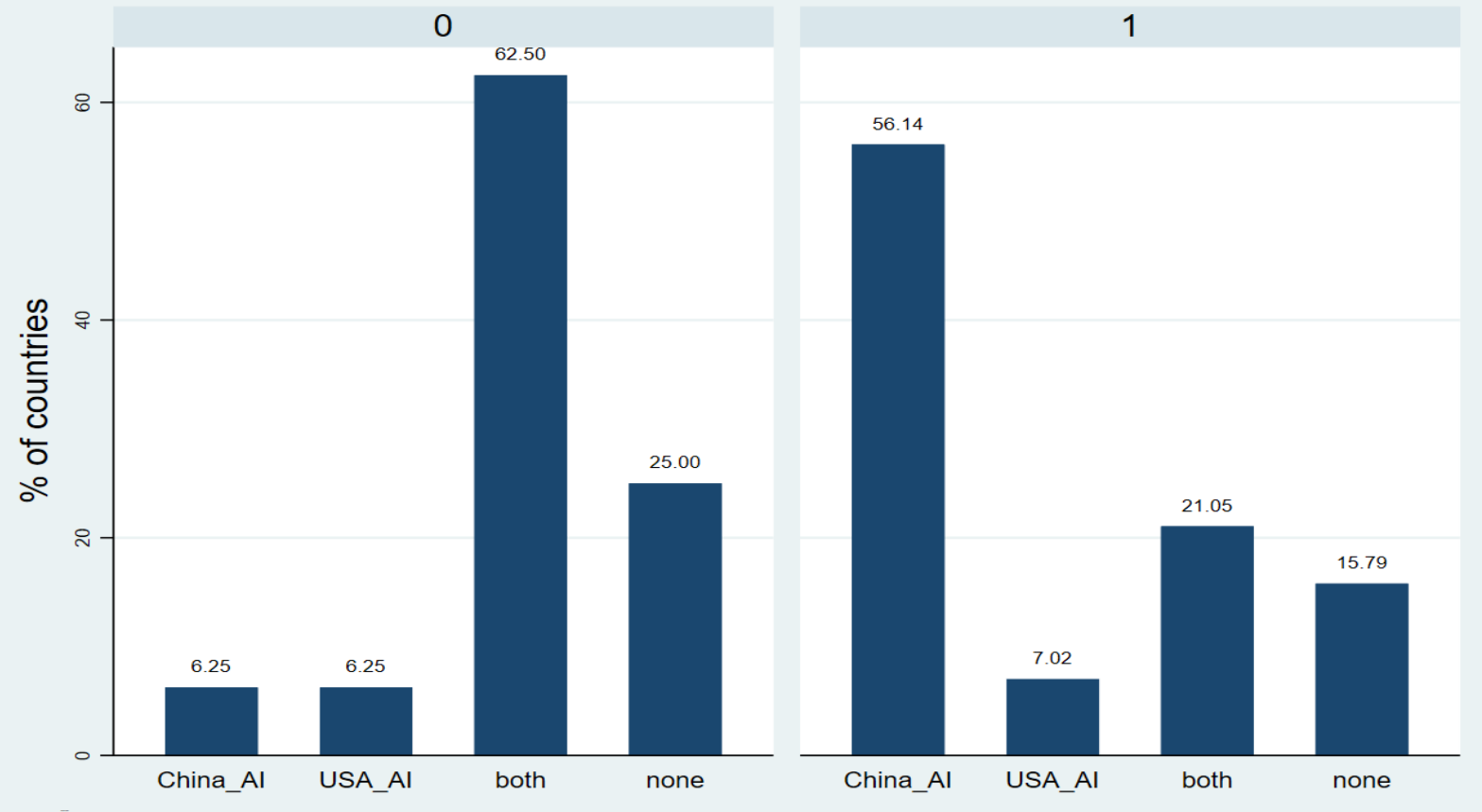


Figure 4: Chinese versus US A.I. import preference in sample countries by ratio of imports from China to from USA

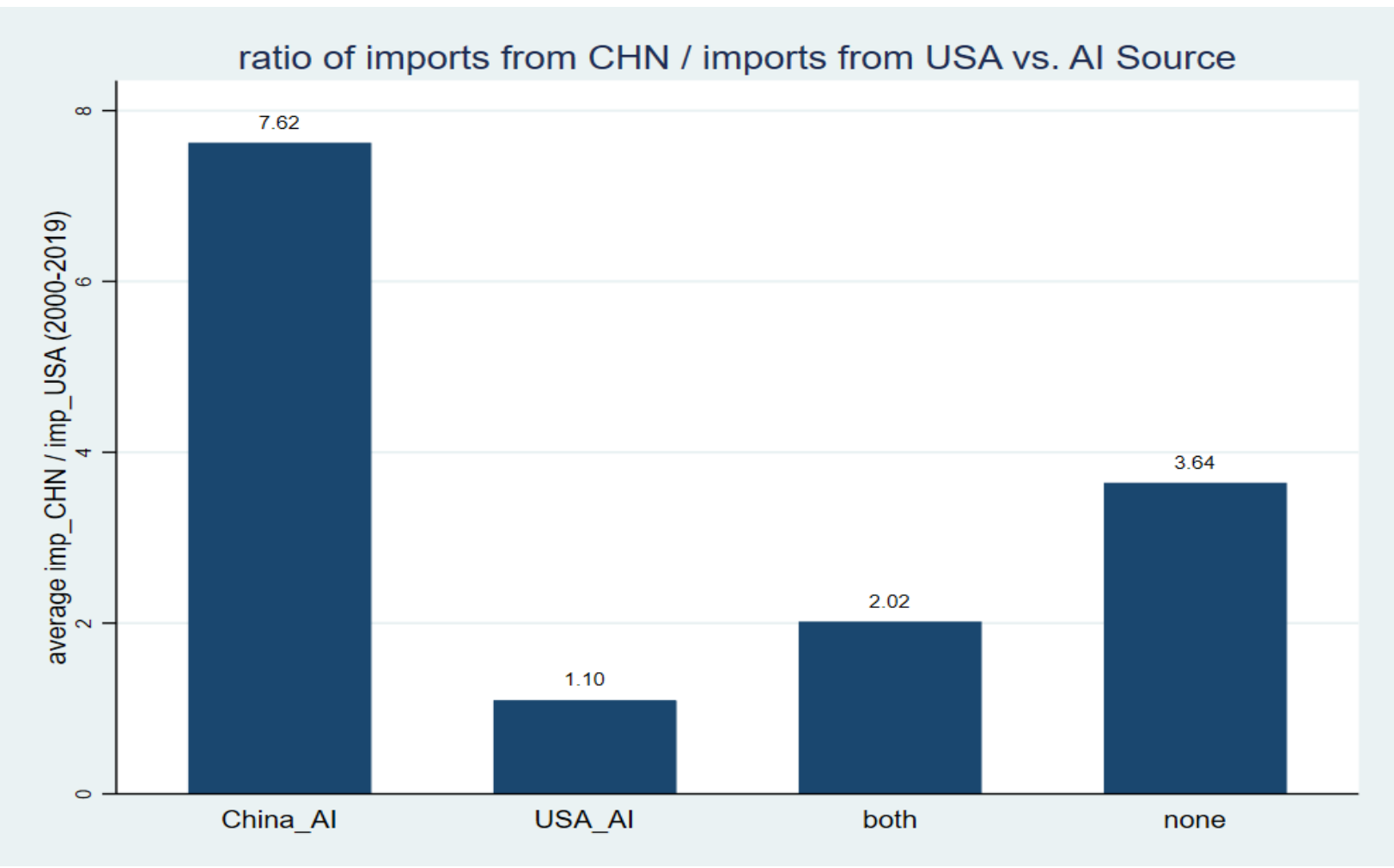


Figure 5: Chinese versus US A.I. import preference in sample countries by the ratio of import growth from China

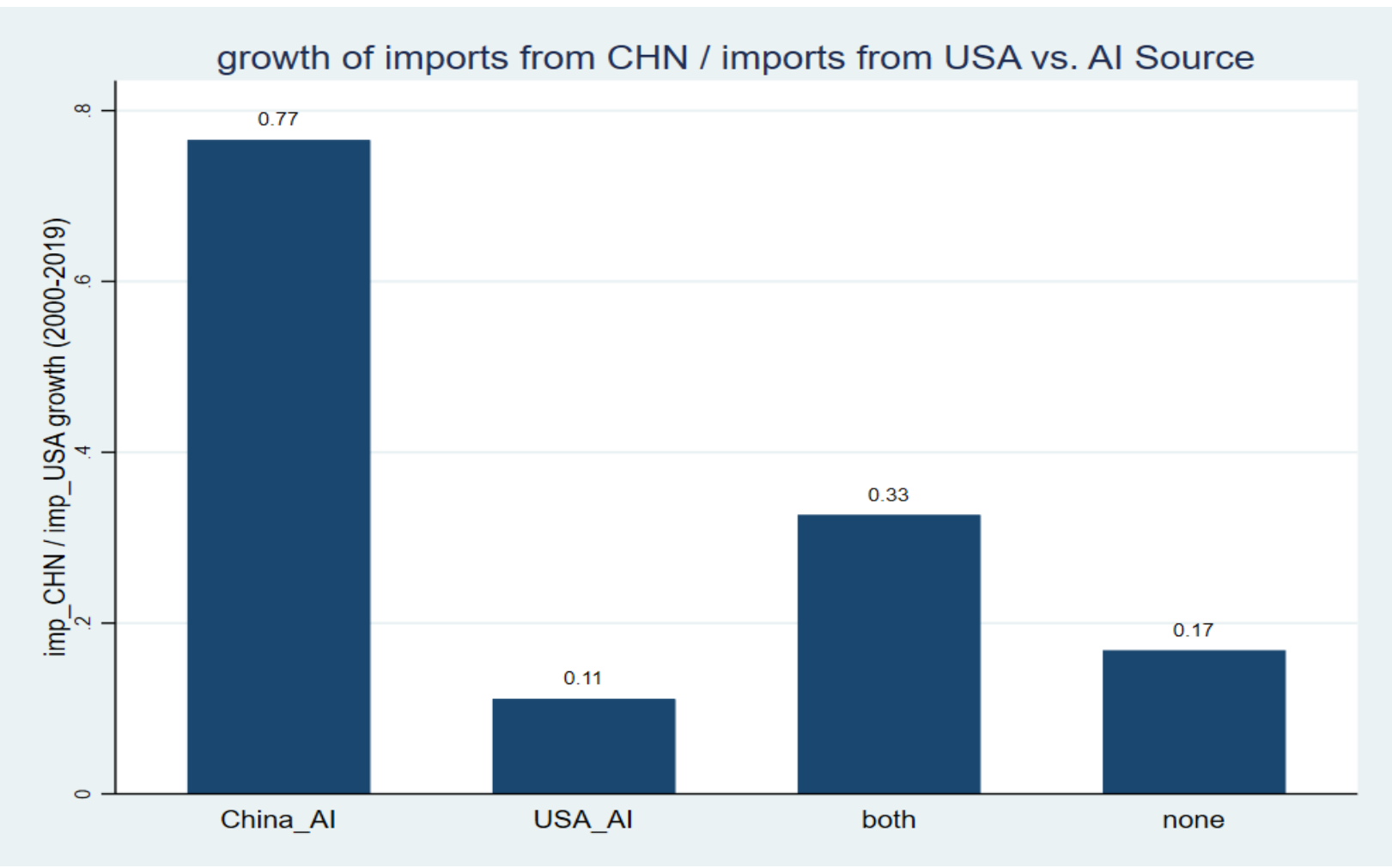


Figure 6: Chinese versus US A.I. import preference in sample countries by the ratio of import growth from the EU

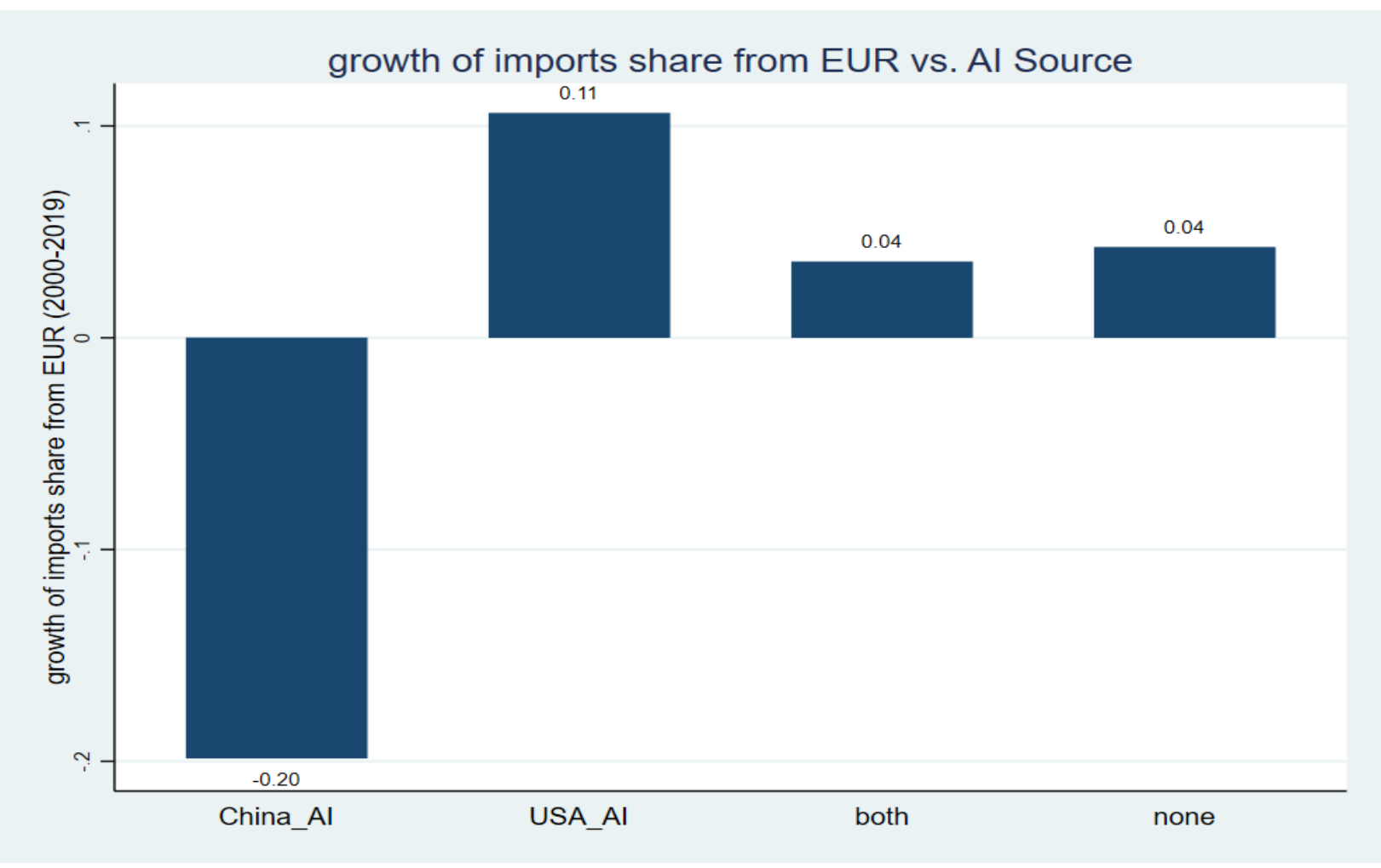


Figure 7: Chinese versus US A.I. import preference in sample countries by surveillancerelated A.I. tools

\section{[AI = social media surveillance] vs. Al Source}

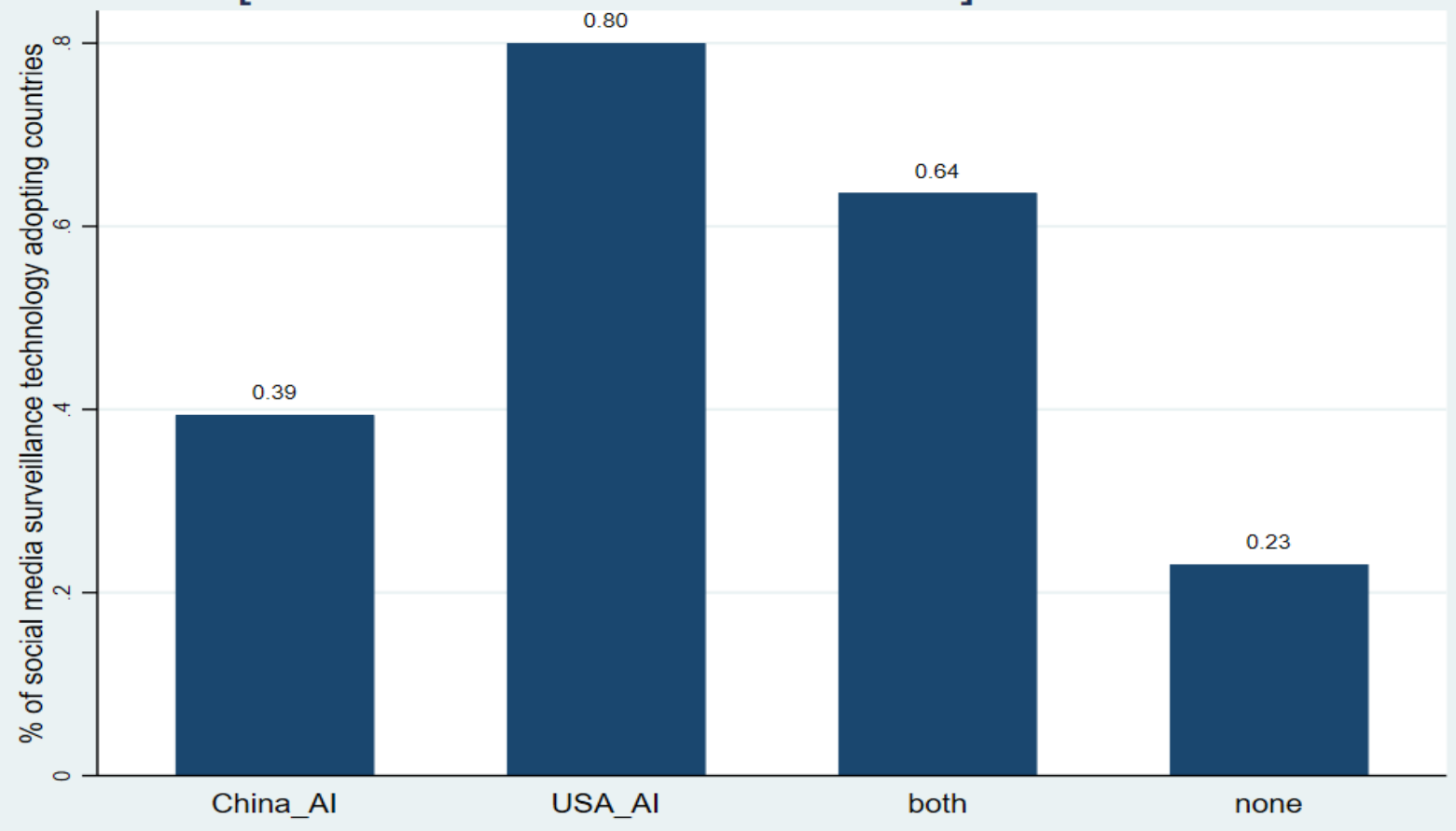


Figure 8: Chinese versus US A.I. import preference in sample countries by smart policingrelated A.I.

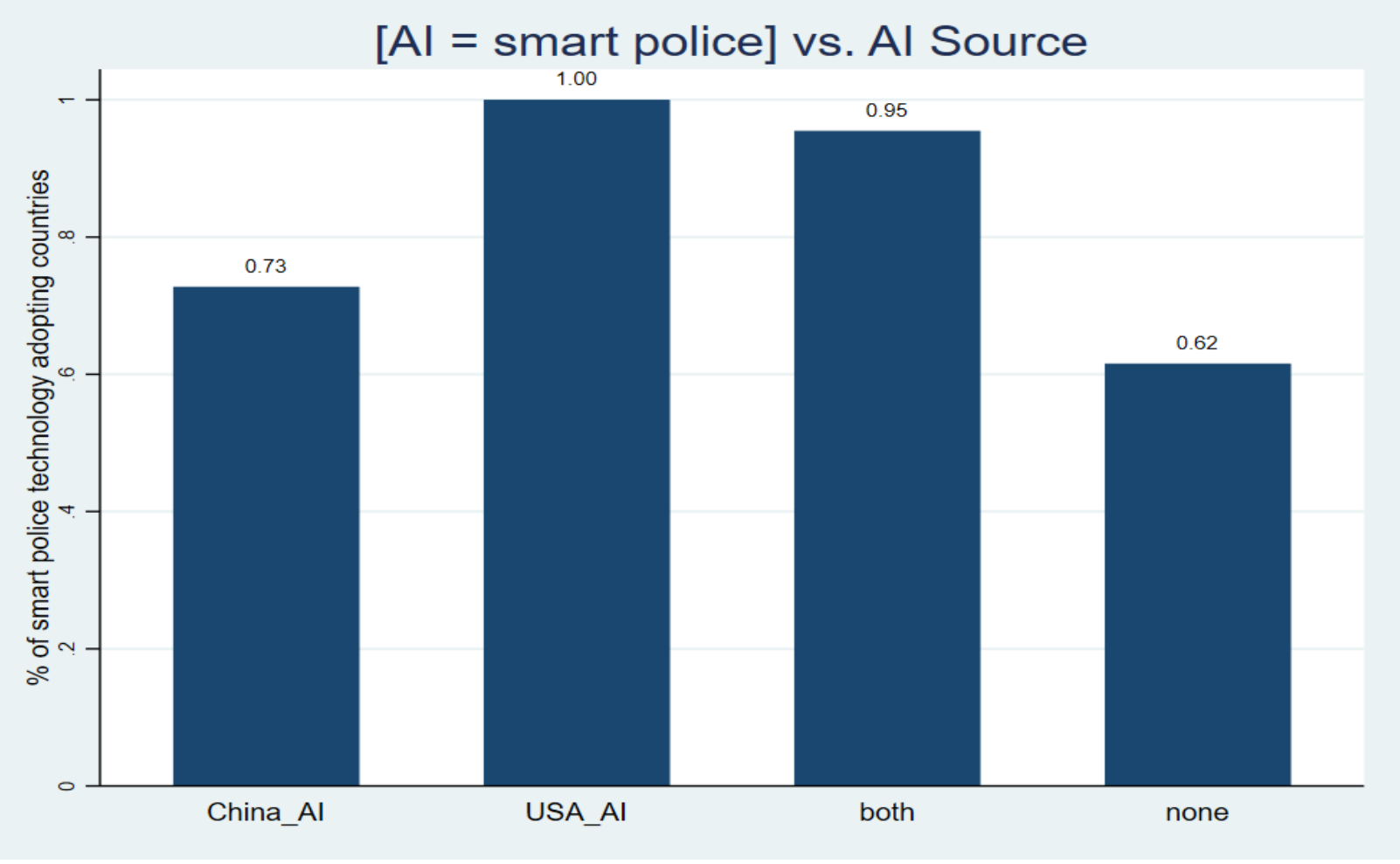


Figure 9: Chinese versus US A.I. import preference in sample countries by regime type

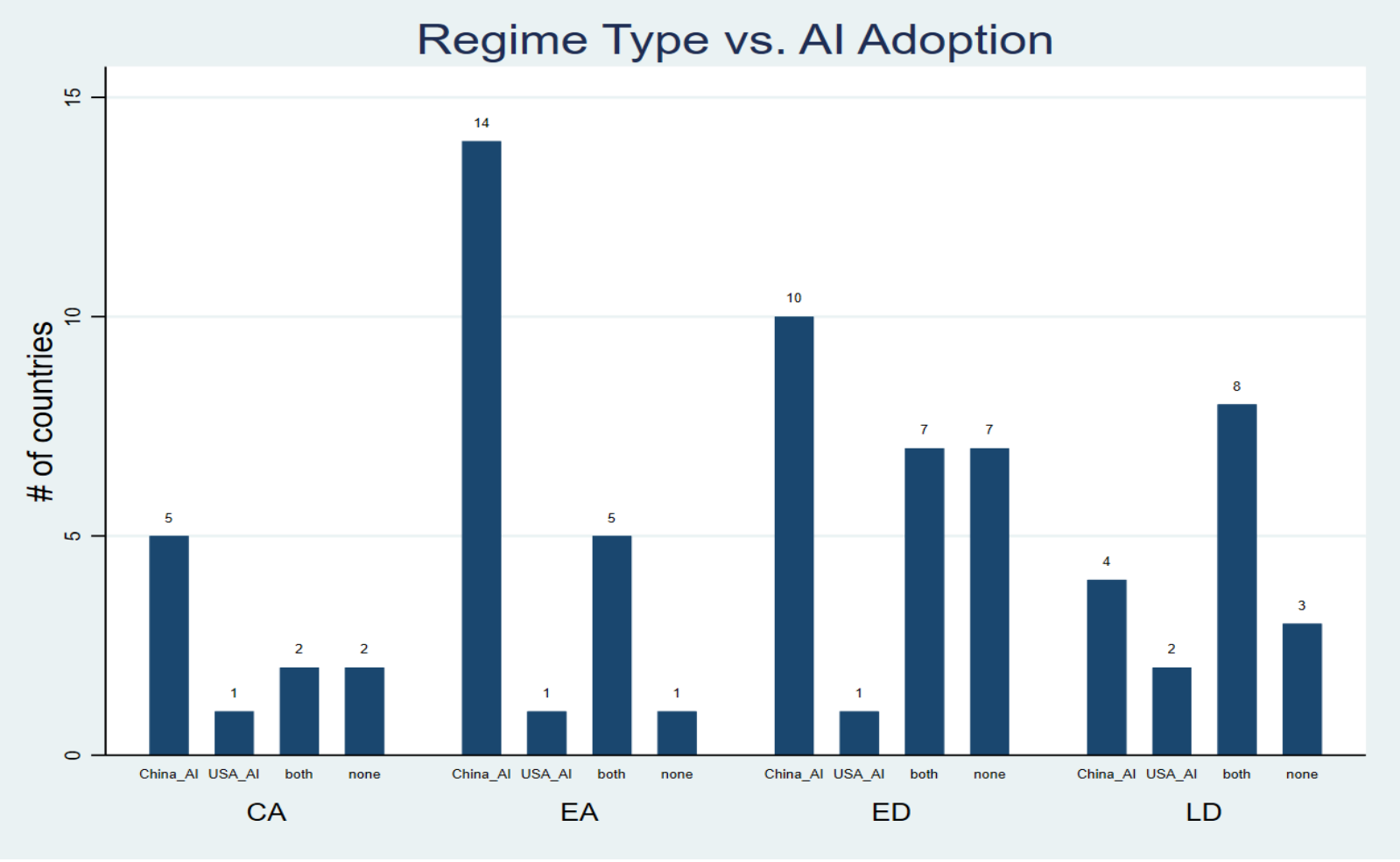


Figure 10: Chinese versus US A.I. import preference in sample countries by freedom scores

Freedom Score vs. Al Adoption

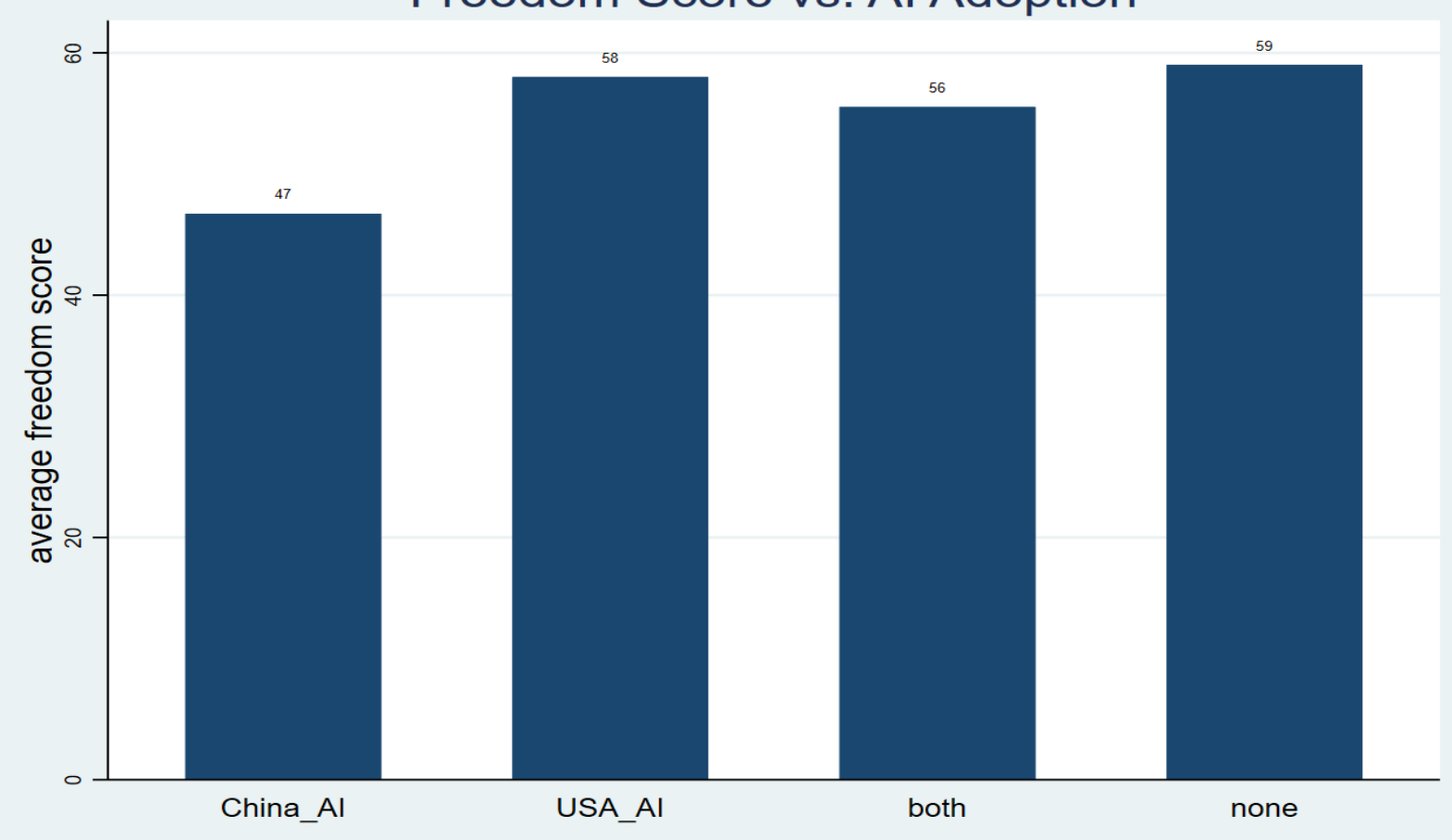


Figure 11: Chinese versus US A.I. import preference in sample countries by GDP per capita GDP per-capita vs. Al Adoption

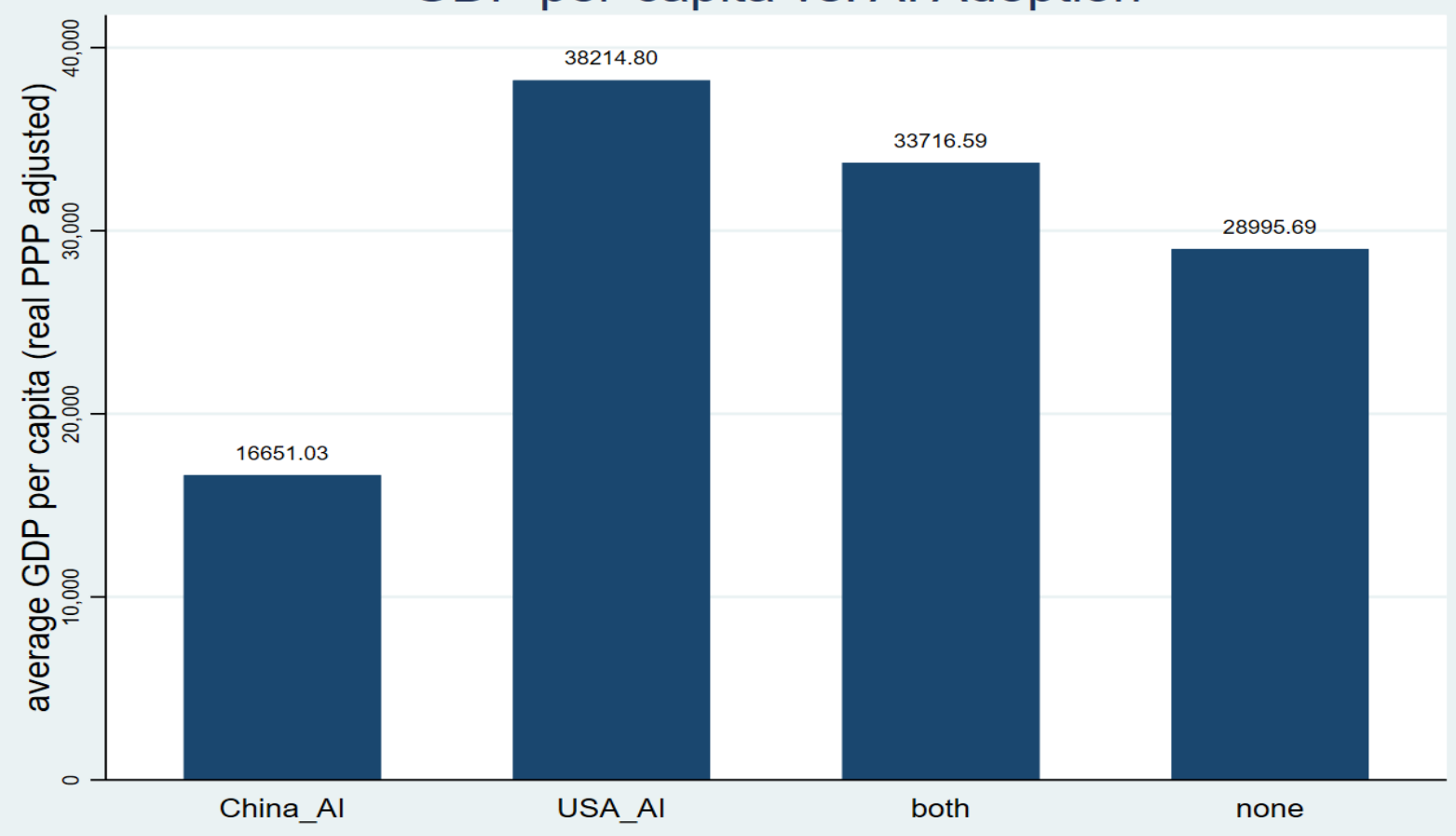


Figure 12: Chinese versus US A.I. import preference in sample countries by military spending

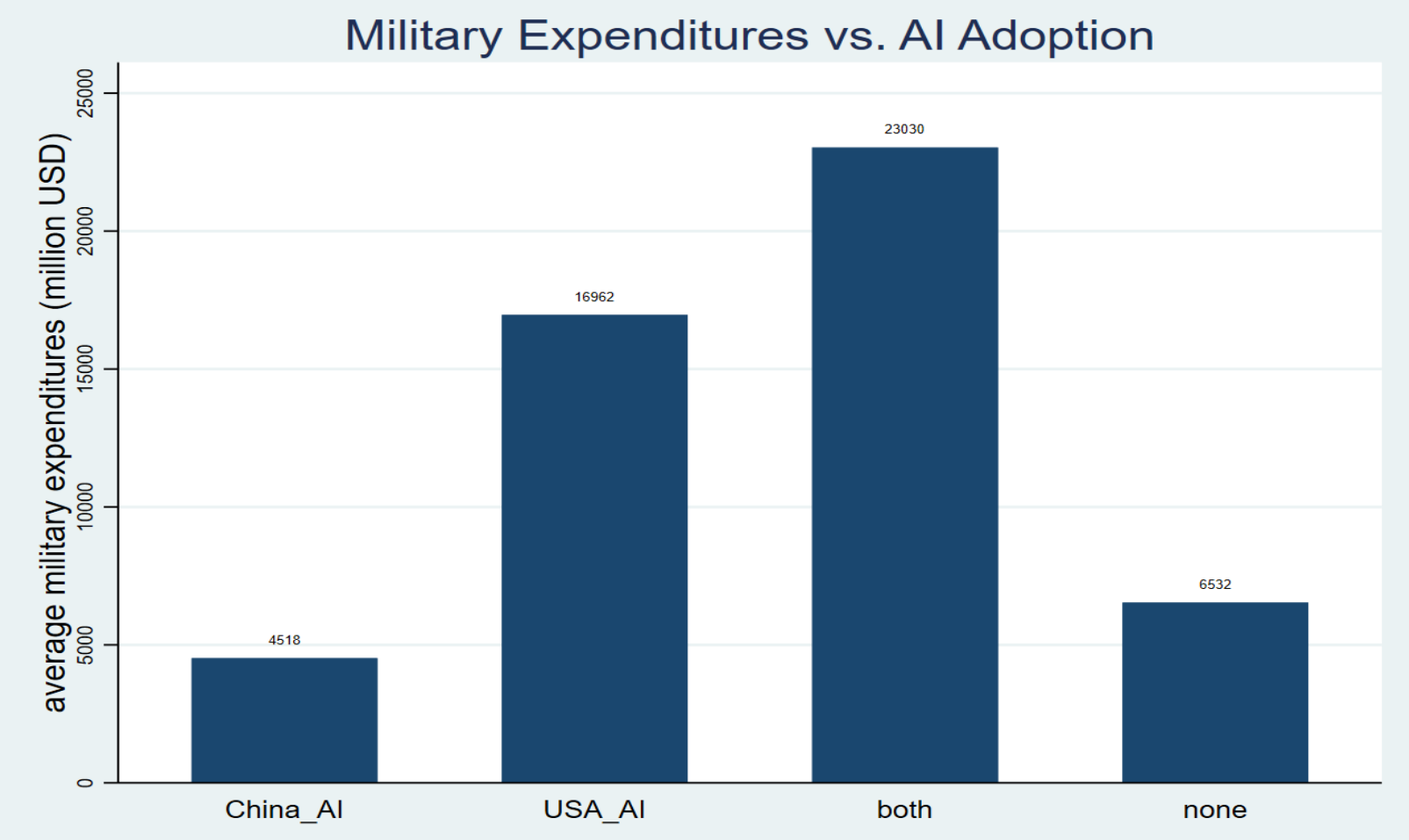


Figure 13: Chinese versus US A.I. import preference in sample countries by region

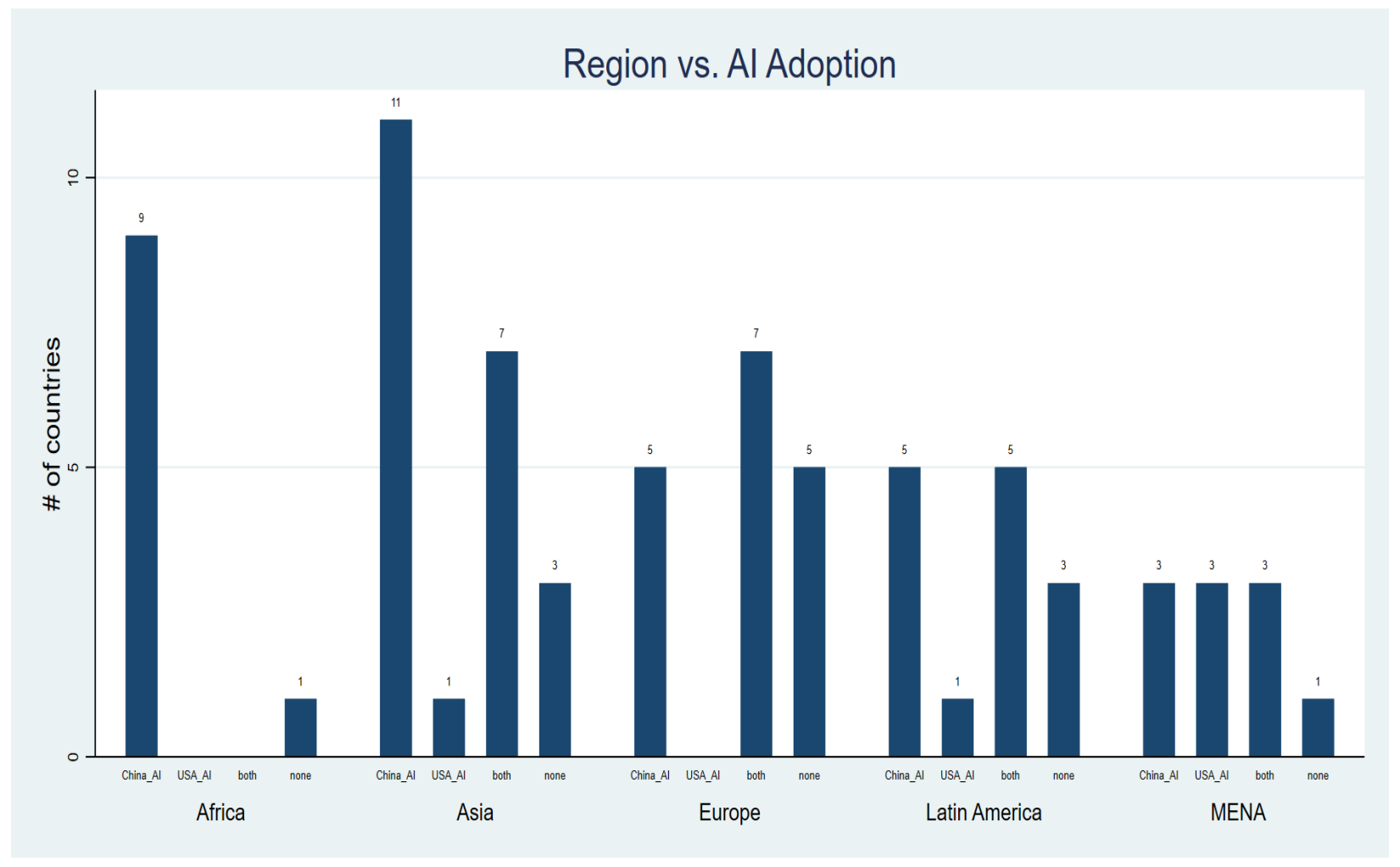


Figure 14: Chinese versus US A.I. import preference in sample countries by level of freedom status

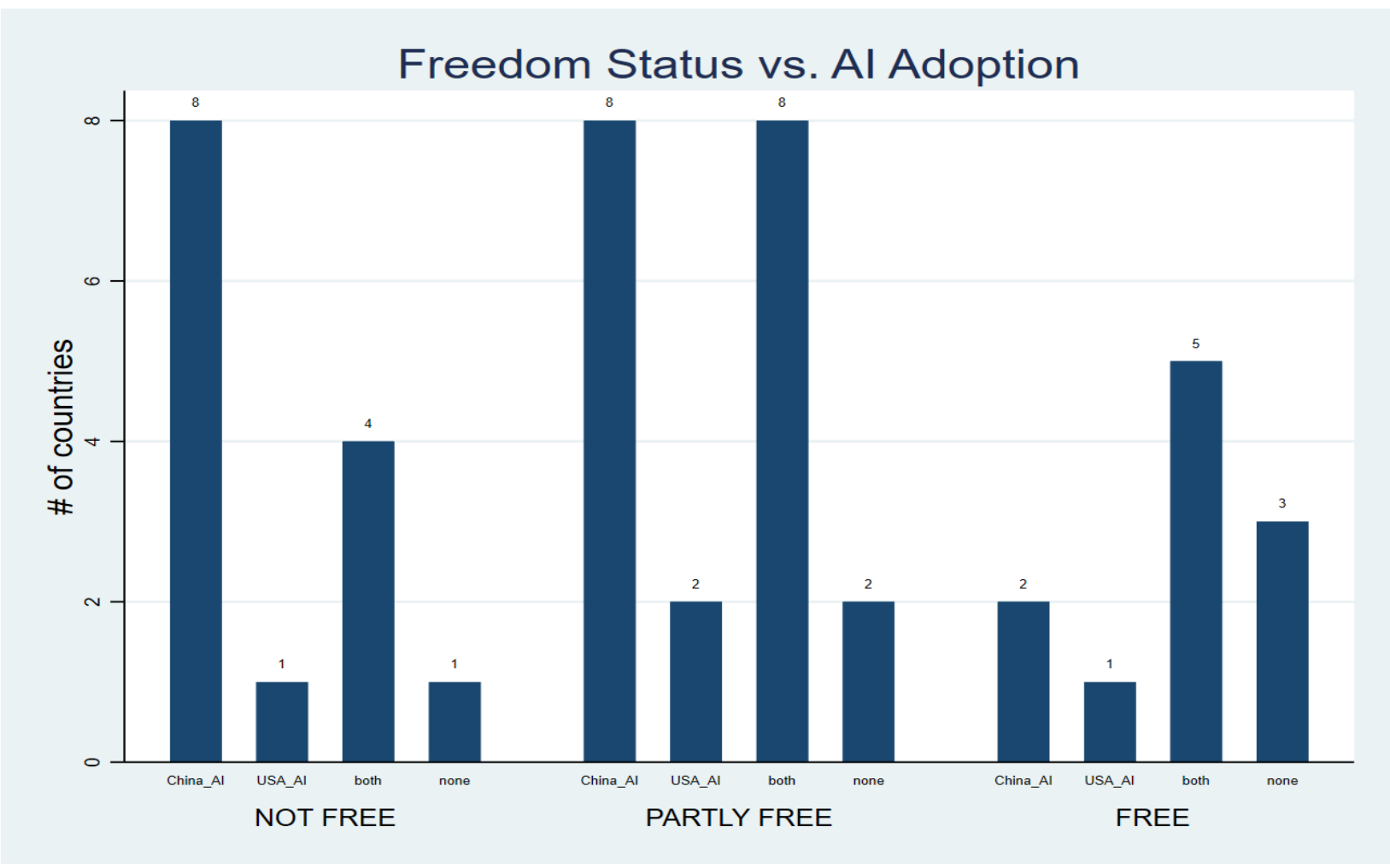


Figure 15: Chinese versus US A.I. import preference in sample countries by polyarchy scores

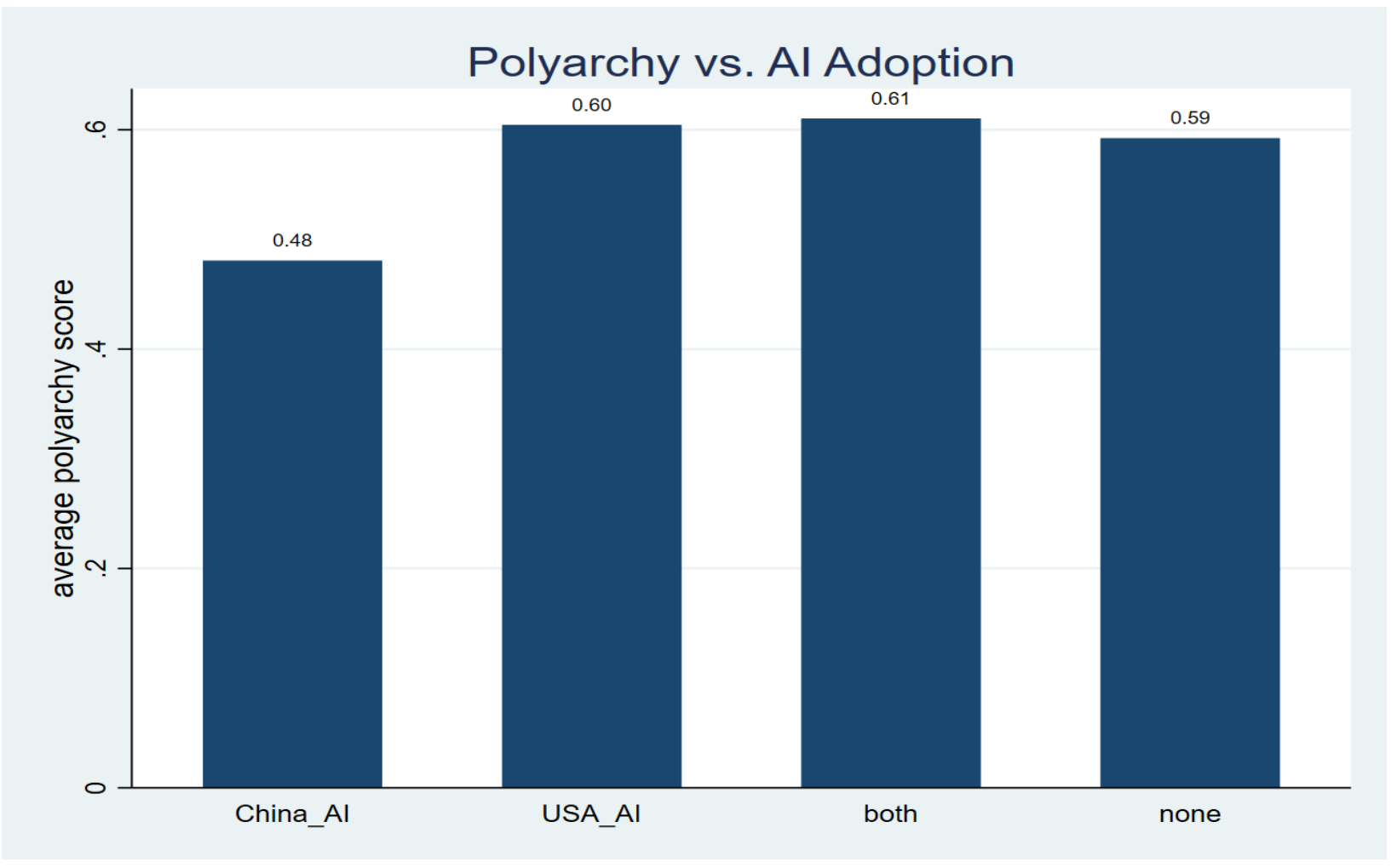


Table 1: MULTINOMIAL LOGIT REGRESSION

\begin{tabular}{|c|c|c|c|c|c|c|c|c|}
\hline Equation & VARIABLES & $\begin{array}{c}\text { (1) } \\
\text { Alsource }\end{array}$ & $\begin{array}{c}(2) \\
\text { Alsource }\end{array}$ & $\begin{array}{c}\text { (3) } \\
\text { Alsource }\end{array}$ & $\begin{array}{c}\text { (4) } \\
\text { Alsource }\end{array}$ & $\begin{array}{c}\text { (5) } \\
\text { Alsource }\end{array}$ & $\begin{array}{c}\text { (6) } \\
\text { Alsource }\end{array}$ & $\begin{array}{c}\text { (7) } \\
\text { Alsource }\end{array}$ \\
\hline \multirow[t]{8}{*}{ China_Al } & Regime $=\mathrm{EA}$ & $\begin{array}{c}1.7228 \\
(1.3402)\end{array}$ & $\begin{array}{c}2.2589 \\
(1.6000)\end{array}$ & $\begin{array}{c}2.1755 \\
(1.5775)\end{array}$ & $\begin{array}{l}1.9412 \\
(1.5645)\end{array}$ & $\begin{array}{c}1.7436 \\
(1.5604)\end{array}$ & $\begin{array}{c}1.7436 \\
(1.5604)\end{array}$ & $\begin{array}{c}1.0466 \\
(1.8036)\end{array}$ \\
\hline & Regime $=\mathrm{ED}$ & $\begin{array}{l}-0.5596 \\
(0.9777)\end{array}$ & $\begin{array}{l}-0.0121 \\
(1.1033)\end{array}$ & $\begin{array}{c}0.0829 \\
(1.0915)\end{array}$ & $\begin{array}{c}-0.0572 \\
(1.1308)\end{array}$ & $\begin{array}{c}0.1264 \\
(1.0801)\end{array}$ & $\begin{array}{c}0.1264 \\
(1.0801)\end{array}$ & $\begin{array}{c}0.6703 \\
(1.4308)\end{array}$ \\
\hline & Regime $=$ LD & $\begin{array}{c}-0.6286 \\
(1.1407)\end{array}$ & $\begin{array}{c}0.4927 \\
(1.4767)\end{array}$ & $\begin{array}{c}1.2213 \\
(1.5065)\end{array}$ & $\begin{array}{c}1.3516 \\
(1.6161)\end{array}$ & $\begin{array}{c}1.2765 \\
(1.5970)\end{array}$ & $\begin{array}{c}1.2765 \\
(1.5970)\end{array}$ & $\begin{array}{c}1.7412 \\
(1.6773)\end{array}$ \\
\hline & LNgdppc_2019 & & & & & $\begin{array}{l}-0.4777 \\
(0.8051)\end{array}$ & $\begin{array}{l}-0.4777 \\
(0.8051)\end{array}$ & $\begin{array}{c}-0.9035 \\
(1.0229)\end{array}$ \\
\hline & LNgdp_2019 & & & & & $\begin{array}{c}0.4279 \\
(0.5459)\end{array}$ & $\begin{array}{c}0.4279 \\
(0.5459)\end{array}$ & $\begin{array}{c}0.7619 \\
(0.5280)\end{array}$ \\
\hline & CHN/US imp. rat. & & & & & & & $\begin{array}{l}-0.0122 \\
(0.0446)\end{array}$ \\
\hline & CHN/US imp. gr. & & & & & & & $\begin{array}{l}2.7650^{*} \\
(1.5816)\end{array}$ \\
\hline & EUR imp. growth & & & & & & & $\begin{array}{l}-3.4151^{*} \\
(1.7561)\end{array}$ \\
\hline \multirow[t]{8}{*}{ USA_AI } & Regime $=\mathrm{EA}$ & $\begin{array}{c}0.6931 \\
(1.8838)\end{array}$ & $\begin{array}{c}1.3961 \\
(2.0514)\end{array}$ & $\begin{array}{l}1.3518 \\
(2.0376)\end{array}$ & $\begin{array}{c}1.3471 \\
(2.0439)\end{array}$ & $\begin{array}{c}5.2275 \\
(3.5103)\end{array}$ & $\begin{array}{c}5.2275 \\
(3.5103)\end{array}$ & $\begin{array}{c}28.8147 * * * \\
(3.2972)\end{array}$ \\
\hline & Regime $=$ ED & $\begin{array}{l}-1.2528 \\
(1.6369)\end{array}$ & $\begin{array}{l}-0.6505 \\
(2.1023)\end{array}$ & $\begin{array}{l}-0.6495 \\
(2.1801)\end{array}$ & $\begin{array}{l}-0.7278 \\
(2.2883)\end{array}$ & $\begin{array}{c}3.4148 \\
(3.8786)\end{array}$ & $\begin{array}{c}3.4148 \\
(3.8786)\end{array}$ & $\begin{array}{c}-124.8285^{* * *} \\
(4.2193)\end{array}$ \\
\hline & Regime $=$ LD & $\begin{array}{c}0.2877 \\
(1.5381)\end{array}$ & $\begin{array}{c}1.9964 \\
(1.7753)\end{array}$ & $\begin{array}{c}2.1330 \\
(1.8358)\end{array}$ & $\begin{array}{c}2.1493 \\
(1.8961)\end{array}$ & $\begin{array}{c}4.6416 \\
(3.5507)\end{array}$ & $\begin{array}{c}4.6416 \\
(3.5507)\end{array}$ & $\begin{array}{l}-4.4278 \\
(3.1447)\end{array}$ \\
\hline & LNgdppc_2019 & & & & & $\begin{array}{l}2.2580^{*} \\
(1.3289)\end{array}$ & $\begin{array}{l}2.2580^{*} \\
(1.3289)\end{array}$ & $\begin{array}{c}104.3610^{* * * *} \\
(3.6983)\end{array}$ \\
\hline & LNgdp_2019 & & & & & $\begin{array}{c}0.8505 \\
(1.1788)\end{array}$ & $\begin{array}{c}0.8505 \\
(1.1788)\end{array}$ & $\begin{array}{c}-4.5430^{* * *} \\
(0.7579)\end{array}$ \\
\hline & CHN/US imp. rat. & & & & & & & $\begin{array}{c}-40.0337 * * * \\
(1.6062)\end{array}$ \\
\hline & CHN/US imp. gr. & & & & & & & $\begin{array}{c}-438.0349^{* * *} \\
(10.2797)\end{array}$ \\
\hline & EUR imp. growth & & & & & & & $\begin{array}{c}302.0774^{* * *} \\
(7.5560)\end{array}$ \\
\hline \multirow[t]{8}{*}{ both } & Regime $=\mathrm{EA}$ & $\begin{array}{c}1.6094 \\
(1.4935)\end{array}$ & $\begin{array}{c}1.9530 \\
(1.7387)\end{array}$ & $\begin{array}{c}1.9871 \\
(1.7161)\end{array}$ & $\begin{array}{c}1.2224 \\
(1.7664)\end{array}$ & $\begin{array}{c}2.5591 \\
(1.6592)\end{array}$ & $\begin{array}{c}2.5591 \\
(1.6592)\end{array}$ & $\begin{array}{c}4.0372 \\
(2.5536)\end{array}$ \\
\hline & Regime $=$ ED & $\begin{array}{c}-0.0000 \\
(1.1417)\end{array}$ & $\begin{array}{c}0.1111 \\
(1.2616)\end{array}$ & $\begin{array}{c}-0.0686 \\
(1.2614)\end{array}$ & $\begin{array}{c}-0.7744 \\
(1.4057)\end{array}$ & $\begin{array}{c}0.1516 \\
(1.4816)\end{array}$ & $\begin{array}{c}0.1516 \\
(1.4816)\end{array}$ & $\begin{array}{c}-0.0096 \\
(1.7183)\end{array}$ \\
\hline & Regime $=$ LD & $\begin{array}{c}0.9808 \\
(1.2160)\end{array}$ & $\begin{array}{c}1.6360 \\
(1.5768)\end{array}$ & $\begin{array}{c}1.2047 \\
(1.7878)\end{array}$ & $\begin{array}{l}1.5110 \\
(1.9485)\end{array}$ & $\begin{array}{c}1.7403 \\
(1.9483)\end{array}$ & $\begin{array}{c}1.7403 \\
(1.9483)\end{array}$ & $\begin{array}{c}2.7003 \\
(2.2363)\end{array}$ \\
\hline & LNgdppc_2019 & & & & & $\begin{array}{c}1.4890 \\
(0.9747)\end{array}$ & $\begin{array}{c}1.4890 \\
(0.9747)\end{array}$ & $\begin{array}{c}1.4455 \\
(1.1832)\end{array}$ \\
\hline & LNgdp_2019 & & & & & $\begin{array}{c}0.2503 \\
(0.4185)\end{array}$ & $\begin{array}{c}0.2503 \\
(0.4185)\end{array}$ & $\begin{array}{c}0.3407 \\
(0.6122)\end{array}$ \\
\hline & CHN/US imp. rat. & & & & & & & $\begin{array}{l}-0.2831 \\
(0.1902)\end{array}$ \\
\hline & CHN/US imp. gr. & & & & & & & $\begin{array}{c}0.4983 \\
(1.8645)\end{array}$ \\
\hline & EUR imp. growth & & & & & & & $\begin{array}{c}2.5039 \\
(3.5205)\end{array}$ \\
\hline \multirow{2}{*}{\multicolumn{2}{|c|}{$\begin{array}{l}\text { Observations } \\
\text { Pseudo R2 }\end{array}$}} & 73 & 73 & 73 & 73 & 72 & 72 & 72 \\
\hline & & 0.0653 & 0.123 & 0.174 & 0.228 & 0.322 & 0.322 & 0.545 \\
\hline
\end{tabular}

Robust standard errors in parentheses ( $\left.{ }^{* * *} p<0.01,{ }^{* *} p<0.05,{ }^{*} p<0.1\right)$

Included Controls: region, population, BRI 


\section{References}

Acemoglu, D. and Robinson, J. A. (2000). Political Losers as a Barrier to Economic Development. American Economic Review, 90(2):126-130.

Alsheibani, S., Cheung, Y., and Messom, C. (2018). Artificial Intelligence Adoption: AIreadiness at Firm-Level. In PACIS 2018 Proceedings, 9.

Aly, H. (2020). Digital Transformation, Development and Productivity in Developing Countries: Is Artificial Intelligence a Curse or a Blessing? Review of Economics and Political Science. Publisher: Emerald Publishing Limited.

Campbell, H. (2008). China in Africa: Challenging US global hegemony. Third World Quarterly, 29(1):89-105. Publisher: Taylor \& Francis.

Castro, D., McLaughlin, M., and Chivot, E. (2019). Who Is Winning the AI Race: China, the EU or the United States? Technical report, Center for data innovation.

Choi, C. and Jee, S. H. (2021). Differential Effects of Information and Communication Technology on (De-) Democratization of Authoritarian Regimes. International Studies Quarterly, 65(4):1163-1175. Publisher: Oxford University Press.

Corrales, J. and Westhoff, F. (2006). Information Technology Adoption and Political Regimes. International Studies Quarterly, 50(4):911-933. Publisher: Blackwell Publishing Ltd Oxford, UK.

Diamond, L. (2010). Liberation Technology. Journal of Democracy, 21(3):69-83.

Druzin, B. and Gordon, G. S. (2018). Authoritarianism and the Internet. Law \& Social Inquiry, 43(4):1427-1457. Publisher: Cambridge University Press.

Evans, P. B. (1995). Embedded Autonomy: States and Industrial Transformation. Princeton University Press.

Fatima, S., Desouza, K. C., and Dawson, G. S. (2020). National Strategic Artificial Intelligence Plans: A Multi-dimensional Analysis. Economic Analysis and Policy, 67:178-194.

Feldstein, S. (2019b). The Road to Digital Unfreedom: How Artificial Intelligence Is Reshaping Repression. Journal of Democracy, 30(1):40-52. Publisher: Johns Hopkins University Press.

Feldstein, S. (September 17, 2019a). The Global Expansion of AI Surveillance. Carnegie Endowment for International Peace.

Frank, M. R., Autor, D., Bessen, J. E., Brynjolfsson, E., Cebrian, M., Deming, D. J., Feldman, M., Groh, M., Lobo, J., Moro, E., Wang, D., Youn, H., and Rahwan, I. (2019). Toward Understanding the Impact of Artificial Intelligence on Labor. Proceedings of the National Academy of Sciences, 116(14):6531-6539. Publisher: National Academy of Sciences _eprint: https://www.pnas.org/content/116/14/6531.full.pdf. 
Franke, U. (2021). Artificial Intelligence Diplomacy: Artificial Intelligence Governance as a New External Policy Tool. Technical report, European Parliament Directorate-General for Internal Policies.

Garcia, D. (2021). Stop the emerging AI cold war. Nature, 593(7858):169.

Gravett, W. H. (2020). Digital Coloniser? China and Artificial Intelligence in Africa. Survival, 62(6):153-178. Publisher: Routledge.

Greitens, S. C. (2020). Dealing with Demand for China's Global Surveillance Exports. Technical report, Brookings Institution.

Haner, J. and Garcia, D. (2019). The Artificial Intelligence Arms Race: Trends and World Leaders in Autonomous Weapons Development. Global Policy, 10(3):331-337. Publisher: Wiley Online Library.

Hausman, J. and McFadden, D. (1984). Specification Tests for the Multinomial Logit Model. Econometrica, 52(5):1219-1240. Publisher: [Wiley, Econometric Society].

Helm, J. M., Swiergosz, A. M., Haeberle, H. S., Karnuta, J. M., Schaffer, J. L., Krebs, V. E., Spitzer, A. I., and Ramkumar, P. N. (2020). Machine Learning and Artificial Intelligence: Definitions, Applications, and Future Directions. Current Reviews in Musculoskeletal Medicine, 13(1):69-76.

Horowitz, M. C. (2018). Artificial Intelligence, International Competition, and the Balance of Power. Texas national security review, 1(3). Publisher: Texas National Security Review.

Horowitz, M. C., Allen, G. C., Kania, E. B., and Scharre, P. (2018). Strategic Competition in an Era of Artificial Intelligence. Center for a New American Security., p. 27 edition.

Johnson, J. (2019). Artificial Intelligence \& Future Warfare: Implications for International Security. Defense \& Security Analysis, 35(2):147-169. Publisher: Routledge.

Kania, E. B. (2021). Artificial intelligence in China's Revolution in Military Affairs. Journal of Strategic Studies, 44(4):515-542. Publisher: Routledge.

Kimber, R. (1991). Artificial Intelligence and the Study of Democracy. Social Science Computer Review, 9(3):381-398. Publisher: Sage Publications Sage CA: Thousand Oaks, CA.

Kliman, D. and Grace, A. (2018). Power Play: Addressing China's Belt and Road Strategy. Technical report, Center for a New American Security.

Lamensch, M. (2021). Authoritarianism Has Been Reinvented for the Digital Age.

Leslie, D., Burr, C., Aitken, M., Cowls, J., Katell, M., and Briggs, M. (2021). Artificial Intelligence, Human Rights, Democracy, and the Rule of Law: A Primer. Technical Report SSRN Scholarly Paper ID 3817999, Social Science Research Network. Available at SSRN 3817999. 
Levy, F. (2018). Computers and Populism: Artificial Intelligence, Jobs, and Politics in the Near Term. Oxford Review of Economic Policy, 34(3):393-417.

Malmborg, F. a. and Trondal, J. (2021). Discursive Framing and Organizational Venues: Mechanisms of Artificial Intelligence Policy Adoption. International Review of Administrative Sciences. Publisher: SAGE Publications Ltd.

Meltzer, J. P. and Kerry, C. F. (2021). Strengthening International Cooperation on Artificial Intelligence. Technical report, Brookings Institution.

Milner, H. V. (2006). The Digital Divide: The Role of Political Institutions in Technology Diffusion. Comparative Political Studies, 39(2):176-199. Publisher: SAGE Publications Inc.

Nemitz, P. (2018). Constitutional democracy and technology in the age of artificial intelligence. Philosophical Transactions of the Royal Society A: Mathematical, Physical and Engineering Sciences, 376(2133):20180089. Publisher: The Royal Society Publishing.

Petralia, S. (2021). GPTs and Growth: Evidence on the Technological Adoption of Electrical and Electronic Technologies in the 1920s. European Review of Economic History, 25(3):571-608.

Polyakova, A. and Meserole, C. (2019). Exporting Digital Authoritarianism: The Russian And Chinese Models. Technical report, Brookings Institution.

Roberts, H., Cowls, J., Morley, J., Taddeo, M., Wang, V., and Floridi, L. (2021). The Chinese Approach to Artificial Intelligence: An Analysis of Policy, Ethics, and Regulation. AI \& SOCIETY, 36(1):59-77. Publisher: Springer.

Rød, E. G. and Weidmann, N. B. (2015). Empowering Activists or Autocrats? The Internet in Authoritarian Regimes. Journal of Peace Research, 52(3):338-351. Publisher: SAGE Publications Ltd.

Schiff, D. S., Schiff, K. J., and Pierson, P. (2021). Assessing Public Value Failure in Government Adoption of Artificial Intelligence. Public Administration. Publisher: Wiley Online Library.

Small, K. A. and Hsiao, C. (1985). Multinomial Logit Specification Tests. International Economic Review, 26(3):619-627. Publisher: [Economics Department of the University of Pennsylvania, Wiley, Institute of Social and Economic Research, Osaka University].

Stier, S. (2015). Political Determinants of E-government Performance Revisited: Comparing Democracies and Autocracies. Government Information Quarterly, 32(3):270-278.

Unver, A. (2018). Artificial Intelligence, Authoritarianism and the Future of Political Systems. Technical Report SSRN Scholarly Paper ID 3331635, Social Science Research Network. 
Viscusi, G., Collins, A., and Florin, M.-V. (2020). Governments' Strategic Stance toward Artificial Intelligence: An Interpretive Display on Europe. In Proceedings of the 13th International Conference on Theory and Practice of Electronic Governance, ICEGOV 2020, pages 44-53, New York, NY, USA. Association for Computing Machinery. eventplace: Athens, Greece.

Wang, P. (2019). On Defining Artificial Intelligence. Journal of Artificial General Intelligence, 10(2):1-37.

Weber, F. D. and Schütte, R. (2019). State-of-the-art and Adoption of Artificial Intelligence in Retailing. Digital Policy, Regulation and Governance, 21(3):264-279. Publisher: Emerald Publishing Limited.

Webster, C. and Ivanov, S. (2020). Robotics, Artificial Intelligence, and the Evolving Nature of Work. In George, B. and Paul, J., editors, Digital Transformation in Business and Society: Theory and Cases, pages 127-143. Springer International Publishing, Cham.

Wright, N. D. (2020). Artificial Intelligence and Democratic Norms. Technical report, National Endowment for Democracy.

Zeng, J. (2020). Artificial Intelligence and China's Authoritarian Governance. International Affairs, 96(6):1441-1459.

Zerfass, A., Hagelstein, J., and Tench, R. (2020). Artificial Intelligence in Communication Management: A Cross-national Study on Adoption and Knowledge, Impact, Challenges and Risks. Journal of Communication Management, 24(4):377-389. Publisher: Emerald Publishing Limited. 